\title{
Prolonged length of stay associated with air leak following pulmonary resection has a negative impact on hospital margin [Erratum]
}

Wood DE, Lauer LM, Layton A, et al. Clinicoecon Outcomes

Res. 2016;8:187-195

On page 187, Abstract, Conclusion subheading, the first sentence was "Patients who develop prolonged air leaks after lobectomy, segmentectomy, or lung volume reduction surgery have the best clinical and financial outcomes". However, it should have been "Patients who develop prolonged air leaks after lobectomy, segmentectomy, or lung volume reduction surgery have costly clinical and financial outcomes."

\section{Publish your work in this journal}

ClinicoEconomics and Outcomes Research is an international, peerreviewed open-access journal focusing on health technology assessment, pharmacoeconomics and outcomes research in the areas of diagnosis, medical devices, and clinical, surgical and pharmacological intervention. The economic impact of health policy and health systems organization also constitute important areas of coverage. The manuscript management system is completely online and includes a very quick and fair peer-review system, which is all easy to use. Visit http://www.dovepress.com/testimonials.php to read real quotes from published authors. 